\title{
Understanding the Government Responsibility and Role of Enterprises' Participation in Disaster Management in China
}

\author{
Feng Kong $1,2, * \mathbb{C}$ and Shao Sun ${ }^{3, *}$ \\ 1 College of Humanities and Development Studies, China Agricultural University, Beijing 100083, China \\ 2 Center for Crisis Management Research, Tsinghua University, Beijing 100084, China \\ 3 National Climate Center, China Meteorological Administration, Beijing 100081, China \\ * Correspondence: kongfeng0824@foxmail.com (F.K.); sunshao@cma.gov.cn (S.S.)
}

Citation: Kong, F.; Sun, S.

Understanding the Government Responsibility and Role of Enterprises' Participation in Disaster Management in China. Sustainability 2021, 13, 1708. https://doi.org/ $10.3390 /$ su13041708

Academic Editor: Ioannis Nikolaou

Received: 7 January 2021

Accepted: 3 February 2021

Published: 5 February 2021

Publisher's Note: MDPI stays neutral with regard to jurisdictional claims in published maps and institutional affiliations.

Copyright: (c) 2021 by the authors. Licensee MDPI, Basel, Switzerland. This article is an open access article distributed under the terms and conditions of the Creative Commons Attribution (CC BY) license (https:// creativecommons.org/licenses/by/ $4.0 /)$.

\begin{abstract}
The natural advantages of enterprises in capital, technology, and equipment make them have great potential in disaster management. How to ensure enterprises participate in disaster prevention and mitigation efficiently is a responsibility that the government must undertake, on the other hand, it can also relieve the pressure of the government. This paper first introduces the continuous improvement of enterprises' role in disaster management. Then, this paper analyzes the political responsibility, legal responsibility, social responsibility, and economical responsibility of the government in an enterprises' participation in disaster management. This paper further analyzes enterprises' deficiencies in disaster management and the multi role of the government in enterprises' participation in disaster management. Finally, this paper puts forward the pathways of the Chinese government to promote enterprises to participate in disaster management.
\end{abstract}

Keywords: disaster management; enterprise participation; government responsibility; government role; emergency management

\section{Introduction}

Under the background of global climate change, rapid urbanization, industrialization, and informatization, frequent natural disasters have become one of the most serious problems facing the sustainable development of society and the economy [1,2].

With the development of information technology, enterprises can transcend the limitation of geographical space and form a network structure closely linked with each other [3]. At the same time, as the basic unit of global economic development, enterprises face the threat of various natural disasters all the time [4]. If an enterprise is damaged by disaster, its impact may spread to other related enterprises along the production chain and supply chain $[5,6]$. In particular, the occurrence of catastrophe will not only cause huge losses to enterprises, leading to the shutdown of enterprises, but also leads to a series of disasters, leading to chaos in regional economic and social development, such as power supply interruption, transportation and telecommunications failures, which will lead to huge social unrest, seriously affecting social production and life [7]. Strengthening internal disaster management can not only maintain social stability, but also help enterprises create a safe external development environment for themselves. Especially, when the enterprise is located in the community, the community is closely related to the safety of the enterprise. Natural disasters that occur in the community will have a significant impact on the development of enterprises, and the safety situation of enterprises will also affect the community. Therefore, enterprises should actively cooperate with communities in disaster management to form a positive interactive relationship [8].

Government has been the only subject of disaster management for a long time $[9,10]$. However, since the non-governmental organizations played an important role in the earthquake of 1995, the role of social organizations in disaster management has become widely known $[8,10]$. The general trend of emergency management in the world is to advocate 
the joint role of the government, private sector, and social organizations. Enterprise is an important cornerstone of economic development at the community, regional, and even national level. The report of the world economic forum in 2013 points out that the role of the private sector in coping with social challenges has become increasingly obvious and effective, and coping with global challenges cannot do without the joint participation of government, private, and public sectors [11]. According to the global assessment report on disaster risk reduction management 2015, it is the responsibility of the government, civil society, and the private sector to work together to create a safer future [12,13]. A more inclusive framework for disaster reduction is crucial to building a better future for mankind [14].

After the "9/11" incident in the United States in 2001, especially after Hurricane Katrina in 2005, the role of private enterprises in disaster response has become increasingly prominent [15]. Since the 2008 Wenchuan earthquake in China, a large number of enterprises have actively participated in emergency rescue and post disaster reconstruction [16]. From the Hanshin earthquake on 17 January 1995 to the East Japan earthquake on 11 March 2011, Japanese enterprises' awareness of disaster participation has been continuously enhanced, and their disaster participation ability has been significantly improved [8]. From the perspective of international disaster management practice, enterprises have become an important subject of disaster management. Especially in recent years, the failure of governments and the efficient participation of enterprises in disaster response further reflect the important role of enterprises in disaster response. Whether enterprises should play a role in disaster management is no longer a question [17]. The real question is what role should enterprises play and how to promote disaster management by establishing effective public-private partnerships. When natural disasters occur, if the enterprise can recover the key water supply, power supply, commodity supply, and service as soon as possible, it can not only maintain the stability of social and economic order, establish a good image of the enterprise, but also protect the interests of shareholders, employees, consumers, suppliers, etc. [11]. On the contrary, it will have a profound negative impact on the local economy and even employment. European and American countries have regarded whether enterprises fulfill their social responsibility as a necessary condition for choosing partners [18].

It is based on the deep understanding of the role of enterprises that the Federal Emergency Management Agency of the United States set up a private sector division to be responsible for the public-private partnership in emergency management after Hurricane Katrina in 2005, in order to give full play to the role of the private sector represented by enterprises in disaster management [10]. Japan has set up a small and medium-sized enterprise department in the national disaster prevention and mitigation organization, which specializes in disaster response and participation of enterprises [8]. It effectively promotes the participation of small and medium-sized enterprises in disaster management. Enterprise disaster prevention has also become an important part of Japan's disaster prevention system. The role of Chinese enterprises in disaster management has also been highly valued in recent years. In 2016, the General Office of the State Council issued the national comprehensive disaster prevention and mitigation plan (2016-2020), pointing out that "actively introduce market forces to participate in disaster management, cultivate and improve the ability of market participants to participate in disaster management". In 2017, the General Office of the State Council issued the 13th five-year plan for the construction of a national emergency response system, which stressed that "we should improve government governance and pay more attention to the role of market mechanism" [10].

The participation of enterprises in disaster management has also attracted the attention of academia. Chinese scholars began to explore enterprise participation in disaster management from the perspectives of business continuity, corporate philanthropy, and disaster response [19]. These studies are helpful to promote the practice and theoretical development of enterprise disaster participation. However, to give full play to the role of enterprises in disaster management, the effective action of the government is indispensable. 
To sum up, enterprise participation in disaster management is not only the inevitable requirement of social transformation, but also the inevitable requirement of promoting sustainable economic development. For China, enterprise participation in disaster management is an important means to integrate social resources and improve the level of disaster management. It is an effective supplement to the formation of China's national emergency management system. As an important part of the national emergency management system, a national disaster management system should include enterprise participation in disaster management as soon as possible. Does the government play a role in enterprises' participation in disaster management? What responsibilities does the government undertake when enterprises participate in disaster management? How should the government give full play to the effective role of enterprises in disaster management? How does the Chinese government promote enterprises to participate in disaster management in practice? These problems are the weak links in the current research and practice of disaster management, and also the focus of this paper. Only when we have a clear understanding of these problems, can we give full play to the due role of disaster management subjects and improve the effectiveness of disaster management.

\section{Government's Responsibility of Enterprises in Disaster Management}

\subsection{Role of Government in Enterprises' Participation in Disaster Management}

As an important social force, enterprises have begun to show their unique advantages [20] and great potential in disaster management in recent years. Especially after the disaster, the strong resultant force formed by enterprises with their own advantages in technology and equipment is more difficult for any government or non-governmental organization to have. Enterprise participation in disaster management fills the gap between the public sector and non-governmental organizations [21]. Enterprises play a key role in the whole cycle of disaster events. Enterprises must be the direct partners of all levels of government and be fully integrated with the government emergency work [22]. However, the participation of enterprises in disaster management does not mean the loss or transfer of government responsibility. On the contrary, enterprises cannot participate in disaster management without the support and guidance of the government. Only when the government takes on the practical responsibility, can the enterprise participate in the disaster management work smoothly, and make the enterprise disaster participation more efficient and orderly [8]. Therefore, helping enterprises better participate in disaster management is also an important part of government disaster management work. In the process of enterprises participating in disaster management, the government needs to bear political responsibility, legal responsibility, social responsibility, and economical responsibility (Figure 1).

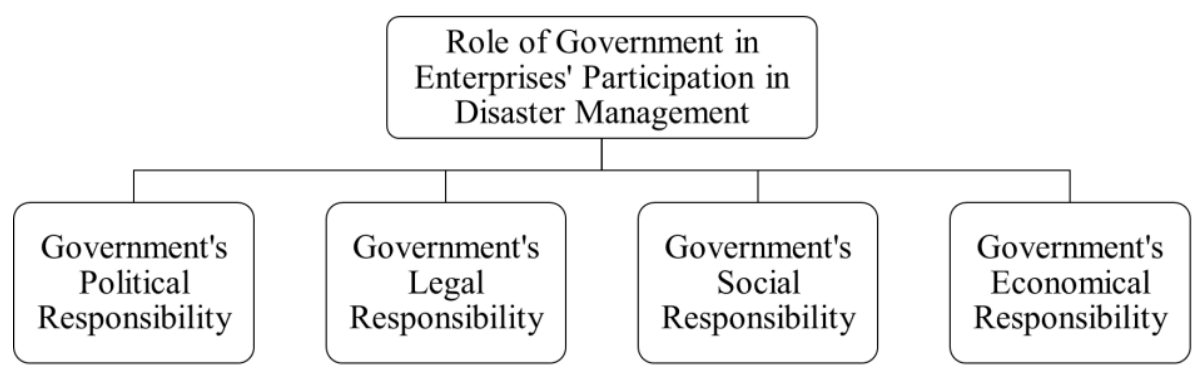

Figure 1. Government's role in enterprises' participation in disaster management.

\subsection{Government's Political Responsibility}

Political responsibility is the responsibility of political officials to formulate public policies in line with public opinion and promote the implementation of public policies in line with public opinions, as well as the condemnation and sanctions they should bear when they fail to perform these duties well. That is to say, the actions of government organizations and their staff must conform to the purpose, and their decisions must 
conform to the will and interests of the people. If the government's decision-making mistakes or behaviors are detrimental to the interests of the country and the people, it will not be investigated by law, but it will bear political responsibility. Political responsibility is the core content of the government responsibility system. In terms of content, in the process of enterprises participating in disaster management, the government mainly shoulders the responsibility of maintaining political rule, consolidating the image of government and ensuring social development. In terms of procedure, the government also shoulders important responsibilities in policy formulation and policy implementation [15].

Mastering the political power of the state is the premise for the government to undertake in terms of political responsibility. If the government, especially the local government, has serious dereliction of duty in disaster participation, which affects enterprises' participation in disaster management, and is condemned by public opinion for violating the basic rights of enterprise citizens, its credibility will be reduced. For example, in the response to Hurricane Katrina in the United States, the Bush Administration sent a large number of troops to Iraq, resulting in a serious shortage of disaster relief manpower, which greatly reduced the support rate of the Bush Administration [8]. In the process of enterprise disaster participation, the government must ensure the basic rights of enterprise citizens, including the safety of enterprise employees' life and property, the right to know the disaster situation, etc. Therefore, in the process of policy-making, the government must fully consider the interests of enterprises and their employees, ensure the safety of the life and property of employees and their families in the process of participating in disaster response, and timely release disaster information, so that enterprises can understand the progress of disasters. At the same time, in the process of the government's implementation of the policy, it should not infringe on the interests of enterprises, but should administrate according to law to protect the life and property safety of enterprises and communities [2]. In the process of enterprise disaster participation, the political responsibilities of the government mainly include maintaining social stability, ensuring information disclosure, and reducing social harm.

The most serious damage caused by disaster events is not the harm to people and property, but the social unrest and disorder, which leads to the fundamental crisis of the whole society. Therefore, how to maintain the stability of social order and people's mind, in the first time after the disaster, is the political responsibility that the government must undertake. For example, in the 2008 Wenchuan earthquake in China, the premier of the State Council led the Earthquake Relief Headquarters of the State Council to Wenchuan immediately after the earthquake, personally directing the earthquake relief work, maintaining the stability of the social order in the disaster areas and alleviating the panic of the people [10]. This sense of maintaining the stability of the social order has become the most important responsibility that the government should undertake in disaster management.

The government has huge political power, so it has access to a lot of information. After the disaster, the government has the responsibility to use its political power to collect and obtain useful information, pass the information to the society and enterprises after screening, and provide public financial funds for the people and enterprises to cope with the disaster. The main feature of disaster response is that the time and information of disaster are extremely limited, which requires decision-makers to make important decisions under heavy pressure. After the disaster, the government should strengthen the information disclosure, open up the official information transmission channel, and provide information support for enterprises to participate in the disaster [16].

The purpose of emergency management, especially disaster response, is to achieve the best effect with the least expenditure in the shortest time $[21,23,24]$. The government employs a large number of disaster management professionals, has advanced technology and equipment, and has rich disaster management experience. Therefore, when a disaster occurs, the government must give full play to these advantages, help enterprises to carry out disaster prevention and mitigation work, and minimize the losses of disasters to society and enterprises. For enterprises, disaster management is also an economic struggle, 
so how to do a good job of cost-benefit analysis for enterprises and help enterprises to minimize economic losses is also the government's duty in the process of disaster response.

\subsection{Government's Legal Responsibility}

The legal responsibility is another important responsibility that the government should undertake in the enterprise disaster participation. The legal responsibility of the government is the legal responsibility of the government to the society where the citizens live. The legal responsibility of the government includes the establishment and improvement of relevant laws, the strict enforcement of laws, the investigation of violations and legal supervision [24]. At present, the legal system of disaster management in China is not perfect [10]. The government should establish and improve relevant laws and regulations, and take the interests of enterprises into consideration. Only with a complete legal framework can enterprises participate in disaster management with laws and regulations.

Both governments and enterprises should strictly abide by relevant laws in disaster management activities. In the process of leading enterprises to engage in disaster management, the government should reward and punish enterprises according to law, so as to encourage or urge enterprises to actively participate in disaster management. The most important thing is that the decision-making of leaders in disaster situation is often made under the condition of limited information and time. In the process of disaster management, the government should clarify its own power boundary and take the overall situation into consideration in the process of decision-making and implementation. The government should avoid making decisions and actions that violate the law, let alone violate the interests of enterprises for its own interests.

As the most powerful means of supervision, legal supervision is the guarantee for the government to fulfill its legal responsibility correctly. In the process of enterprises participating in disaster management, the government's work and the enterprises' work will be staggered and overlapped, and even leadership problems will appear. Therefore, the government has the responsibility and obligation to make its own disaster management work transparent, and require the legal department to effectively supervise its disaster management work, so that the government can constantly adjust the administrative behavior to ensure the legitimacy and effectiveness of disaster management work when helping enterprises to carry out disaster management work. In addition to legal supervision, the government should also strengthen its own internal supervision and social supervision to ensure the legitimacy of administrative acts.

\subsection{Government's Social Responsibility}

Social responsibility means that the government should manage the country and society from the perspective of fairness and justice, so as to make the country and society in a harmonious and orderly state. Compared with other responsibilities, social responsibility is a higher level of government responsibility. It is necessary to emphasize the government's social responsibility of serving the society and promoting fairness, which is the necessary requirement of perfecting the government's social governance function, and also the proper meaning of establishing a service-oriented government. It is the government's duty to run the society well, coordinate the social relations, and promote the orderly interaction of the society [10].

The government should give the employees sufficient social security in the process of enterprises' participation in disaster management. Especially when disasters threaten the life and property safety of enterprise employees and their families, the government has the obligation to rescue them and ensure their basic life. For example, the government has the responsibility to establish disaster relief funds for enterprises to ensure the basic life of enterprise employees and their families [19]. In addition, when enterprises participate in disaster response, the government has the responsibility to ensure the stability of community order and avoid anarchy and disorder. The government should take reasonable measures to guide and help enterprises to participate in emergency management and pro- 
tect enterprises from the impact of disasters to the greatest extent. Timely assistance should be given to those enterprises that have suffered severe damage and those who are unable to participate in disaster relief. Specifically, in the process of enterprise disaster participation, the government should at least undertake the social responsibility of optimizing resource allocation, strengthening the construction of disaster prevention and control infrastructure, and increasing the investment in disaster prevention and mitigation education.

The government has the function of social governance, the most important aspect of which is to optimize the allocation of resources by political means to achieve social equity. On the one hand, the basis for enterprises to participate in disaster management depends on their own conditions. On the other hand, it depends on the government's macrocontrol [19]. The government should give full consideration to disaster factors when formulating financial policies, and help enterprises to achieve effective disaster prevention and mitigation work through targeted funds and policies. For example, the government should give appropriate assistance to the enterprises in the disaster prone areas and those enterprises that cannot afford the disaster expenses, so that these enterprises can become the main body to participate in the disaster management, rather than the objects to be rescued when the disaster occurs.

The private enterprises hold a lot of infrastructure, in many countries, especially in Western capitalist countries. For example, $85 \%$ of the infrastructure in the United States is in the hands of private enterprises [8]. Therefore, private enterprises bear important or even major responsibilities in infrastructure construction. However, the government is mainly responsible for infrastructure construction in China, including the construction and maintenance of disaster prevention and control facilities. Enterprises are in a passive position in the construction of disaster prevention and control. Generally, the construction of infrastructure will reduce the vulnerability of communities and enterprises in disasters. Therefore, the government must vigorously strengthen the infrastructure construction of disaster prevention and control, increase investment, and improve professionalism, so as to ensure community safety.

The government's investment in disaster prevention and mitigation education is complementary to the investment in infrastructure construction. At present, there are some problems in enterprise managers and their employees, such as lack of social responsibility, weak awareness of disaster prevention and mitigation, lack of professionalism in disaster response and enthusiasm for participation. To a large extent, these problems can be solved through education. Disaster preparation is an important link in the process of disaster management. Therefore, the government has the responsibility to increase the education of disaster prevention and mitigation. Especially for enterprises, the government should provide public financial support for the development of disaster education, and regularly send professional personnel to help enterprises carry out disaster prevention and mitigation training. For large enterprises, the government should formulate corresponding policies to urge them to carry out disaster training and disaster education regularly, and the government has the obligation to do a good job of supervision.

\subsection{Government's Economical Responsibility}

Economical responsibility means that the government should help enterprises to share disaster losses by formulating relevant policies and reconstruction plans, and orderly attract and guide capable enterprises to participate in the recovery and reconstruction of disaster areas. Because the government's economical responsibility involves the enterprise's own post disaster recovery and production, and the policy guarantee of the enterprise's investment in the disaster area's recovery and reconstruction, the government's economical responsibility includes that when the disaster exceeds the enterprise's own capacity, the government should be the ultimate fundraiser of the disaster [25]. Therefore, from this point of view, the economic responsibility of the government is closely related to its political, social, and legal responsibilities. Specifically, the government's economic responsibility in disaster participation includes at least the following two aspects. 
The first is to formulate relevant financial and economic measures. For example, through disaster insurance, disaster lottery, disaster bonds, hedge funds, and other related financial and economic measures, effectively apportion the greater impact of disasters, especially catastrophe on enterprises [6]. At the same time, through these financial and economic measures, we can effectively distinguish which disaster risk enterprises can bear, which disaster risk enterprises need to prevent, which disaster risk enterprises need to share and transfer, and which disaster risk needs to be covered by the government. The government should support local enterprises to recover and rebuild as soon as possible through relevant policies in areas with serious damage to enterprises and heavy employment pressure after the catastrophe. These financial and economic measures can effectively help enterprises understand and practice disaster management [26].

The second is to make plans for the recovery and reconstruction of the disaster areas. The recovery and reconstruction of the disaster area after the catastrophe is related to the immediate interests of the people in the disaster area and the long-term development of the disaster area. The task of post disaster recovery and reconstruction is generally arduous, complex, and urgent. Government participation alone will cause huge financial pressure. The enterprise has the advantages of capital and materials, channel guarantee, and standardized construction experience $[5,27]$. The government should precisely define the allocation of powers and responsibilities for enterprises to participate in disaster management in the recovery and reconstruction planning, scientifically determine the main functions of enterprises in different regions through careful planning, optimize the urban and rural distribution, population distribution, industrial structure and productivity distribution of enterprises through careful organization, and rebuild the material and spiritual homes through careful implementation. So that the people in the disaster areas will win new development opportunities in the process of recovery and reconstruction, and promote the harmony between human and nature.

To sum up, the government should pay attention to grasp from two aspects whether it is to fulfill political responsibility, legal responsibility, social responsibility, or economical responsibility. On the one hand, in the process of formulating policies and laws, the government should fully reflect the importance of enterprises, and bring enterprises' participation in disaster management into the track of the policy and legal system, which is the premise for the government to help and guide enterprises to participate in disaster management. On the other hand, the government should strictly abide by the laws and regulations in the specific operation process, and fully protect the interests of enterprises in the process of disaster management.

\section{Deficiencies of Enterprises in Disaster Management}

The government has the responsibility to grasp the reasonable allocation of public resources for disaster management at a macro level, and regulate and restrict the behavior of itself and enterprises in disaster governance by means of legal construction. In addition, enterprises have specific needs in the process of disaster participation, and there are some shortcomings and deficiencies in some aspects. The government has the responsibility to help enterprises overcome these shortcomings, so that enterprises can enhance their willingness and ability to participate in disasters on the basis of constantly improving their disaster management level.

Enterprises need a good development environment (Figure 2). Because of the profitmaking nature of enterprises, it is impossible for enterprise owners to invest a large amount of capital, technology, and personnel into the optimization of the surrounding environment, especially in disaster management. The development of enterprises depends on the situation of their communities. The investment in disaster management and the ability to participate in disaster management depend on the improvement of the overall disaster prevention level of the community. Enterprises are facing external competition in the process of development. The pressure of market competition also forces enterprises to put a lot of energy and capital into disaster management. Further, enterprises must keep the 
balance between fulfilling their social responsibilities and pursuing economic profits all the time. Many enterprises in China have the advantages and potential of disaster participation, and also have the willingness to participate in disasters. However, due to the pressure of the environment and the need for development, they have to weaken their awareness of disaster participation. Even if enterprises can actively participate in disaster management and cooperate with the government to deal with disasters, this cooperation is also very unstable. Enterprises' investment in capital, personnel, and technology will be reduced at any time due to market changes.

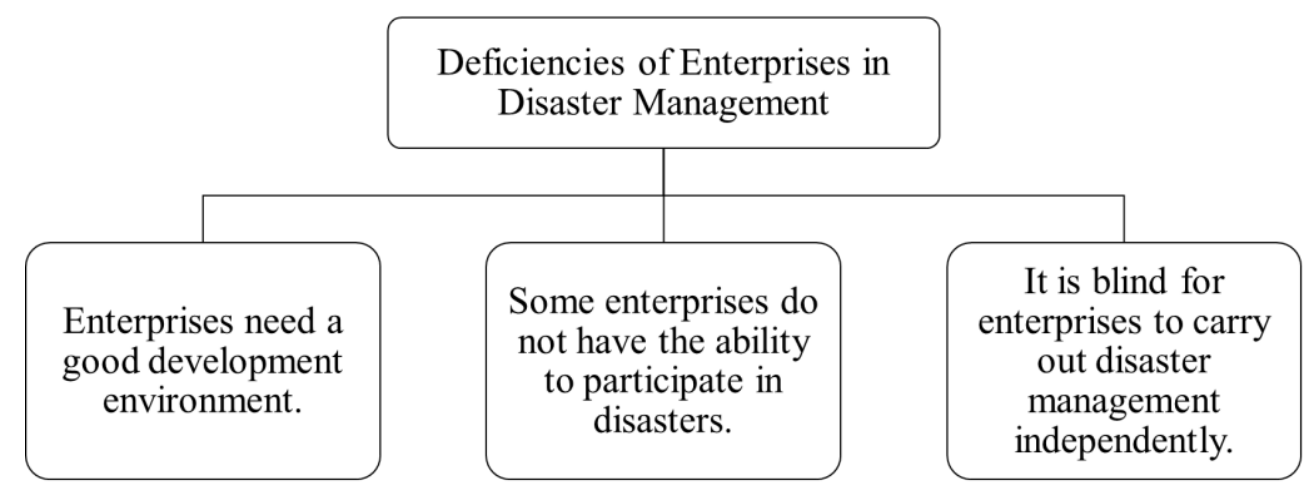

Figure 2. Deficiencies of enterprises in disaster management.

Some enterprises do not have the ability to participate in disasters (Figure 2). The scale of enterprises is the most important factor that affects the disaster prevention of enterprises. Larger enterprises often have better disaster preparedness than small enterprises. For example, China's state-owned large and medium-sized enterprises and other large-scale enterprises have strong capital strength, and their sufficient reserve funds can be used for disaster management. However, for small enterprises, it is difficult for managers to use limited funds for disaster management due to their small scale and lack of funds. In addition, we should pay special attention to that all forms of enterprises will also affect the tendency of enterprises to participate in disaster management to a great extent. For example, the owners who acquire enterprises by leasing are often reluctant to invest too much money in disaster management [10] because this will bring heavy burden to the enterprise owner. Moreover, from the perspective of ownership, the leaseholder has no obligation to bear the losses caused by non-human factors.

It is blind for enterprises to carry out disaster management independently (Figure 2). Like the government's disaster management, there are a series of congenital deficiencies in enterprises' participation in disaster management. There are many reasons for these defects, which are difficult to overcome by enterprises themselves. For example, although enterprises have abundant funds, due to the lack of experience and guidance, the investment in disaster prevention and control is likely to be ineffective. In addition, because some enterprises cannot define the boundary of power with the government, the phenomenon of ultra vires and power confusion in the process of disaster participation often appear. The ambiguity of the power boundary makes the government and enterprises have the overlapping of disaster management and the conflict of power, which will greatly hinder the disaster relief work. Although the enterprises based in the community can be familiar with the situation and needs of the community, the enterprise managers often do not have the ability to make a macro grasp of the disaster, and they do not know what the government has done and what enterprises need to do. Therefore, when enterprises participate in disaster management, they often overlap with the government's disaster management work, resulting in the waste of resources, which will greatly affect the effectiveness and enthusiasm of enterprises to participate in disaster management. 


\section{Specific Measures for Government to Ensure Enterprises in Disaster Management 4.1. Multi Role of Government in Enterprises' Participation in Disaster Management}

As the core subject of disaster management, the government needs to play a leading role in the process of emergency management (Figure 3). In order to improve work efficiency, the government must develop and utilize various social forces including enterprises to participate in disaster management. For enterprises, the main role of the government is to create good conditions for enterprises to participate in disaster management and do a good job in service. Specifically, the most important work of the government in enterprise participation in disaster management is reflected in two aspects. On the one hand, the government needs to fully absorb the power of enterprises in the process of emergency management system construction, and incorporate enterprise emergency management and enterprise disaster participation into the national emergency management system. On the other hand, through the system construction, the government endows enterprises with the rationality and legitimacy of disaster participation, clearing away institutional barriers and providing a favorable environment for enterprises to participate in disaster management.

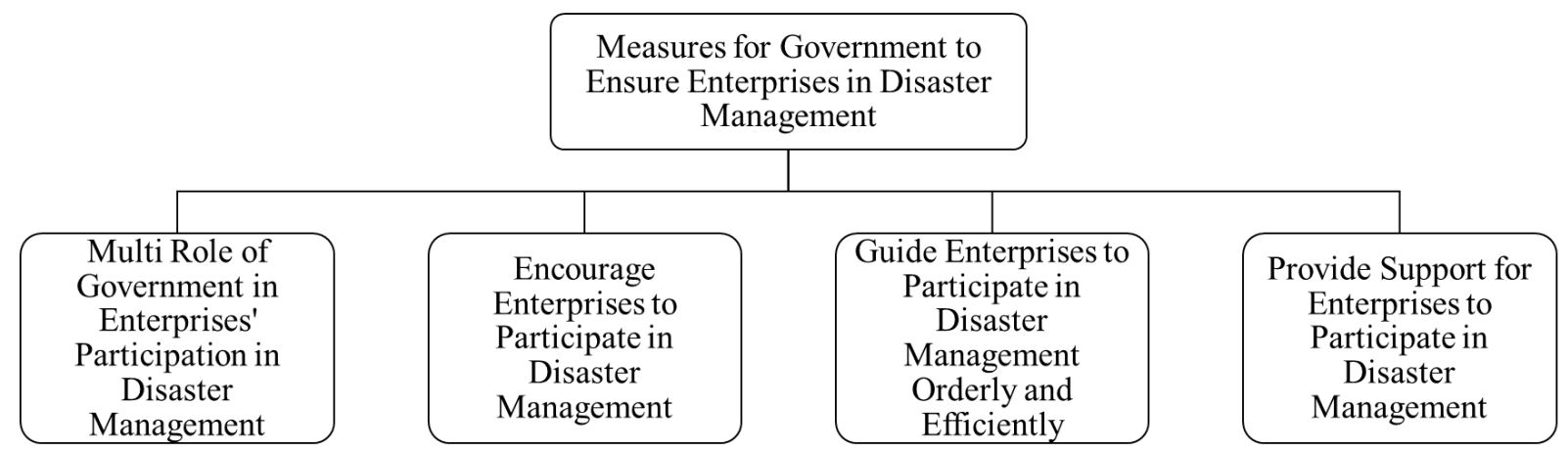

Figure 3. Measures for government to ensure enterprises in disaster management.

\subsection{Encourage Enterprises to Participate in Disaster Management}

On the one hand, as a profit-making economic organization, the intrinsic motivation of enterprises to protect their own property from losses drives enterprises to participate in disaster management activities. On the other hand, to some extent, this motivation conflicts with the enterprise's goal of pursuing maximum interests, which makes the enterprise's participation in disaster management passive and lagging. For enterprise managers, when making decisions, they need to balance the relationship between disaster management expenditure and income, which will lead to conservative decision-making. The government has the function of social governance, and its powerful political power enables it to mobilize all social forces to participate in disaster relief and jointly protect social security and stability. Therefore, enterprises should be encouraged to participate in disaster management (Figure 3). Through a series of reward and punishment measures, the government can promote enterprises to do their best to participate in disaster management and give full play to their potential. In addition, the government needs to take measures such as disaster prevention and mitigation education, ideological education, and public opinion propaganda to make enterprises realize that participating in disaster management is an important performance of enterprises' social responsibility. In addition, enterprises have the responsibility to jointly shoulder the heavy responsibility of disaster management together with the government and other organizations. Policy encouragement is the most effective driving force for enterprises to actively participate in disaster management [8]. The government formulates a series of targeted policies to provide convenience for enterprises to participate in disaster management, and provide certain financial, technical, and policy support. This is not only conducive to the enterprises themselves to prepare for 
disaster prevention, but also conducive to the economic development of enterprises, so as to improve the enthusiasm of enterprises to participate in disaster management.

\subsection{Guide Enterprises to Participate in Disaster Management Orderly and Efficiently}

The effectiveness of enterprise participation in disaster management directly affects the efficiency of enterprise disaster management. There are various ways for enterprises to participate in disaster management, but which way should be adopted to participate in disaster management needs the macro guidance of the government (Figure 3). When enterprises participate in disaster management, they often only rely on their own experience. They lack sufficient knowledge about whether the methods and approaches adopted are effective and whether the decision-making is scientific and feasible. The government's longterm macro-control and abundant information make it have a more objective understanding of the feasibility of enterprises' decision-making and the scientificity of management methods. The government can guide enterprises more reasonably and improve the rationality of methods and decision-making in the process of disaster management. The government should establish relevant disaster prevention and mitigation institutions, issue corresponding policies, and make enterprises clearly understand the methods and ways to participate in disaster management through effective publicity, so as to realize resource allocation more reasonably, and avoid conflicts with government power, resource overlap, and decision-making in the process of participating in disaster management [9]. In addition, the government should strengthen the guidance of enterprises to participate in disaster management, which is conducive to the mode of enterprise disaster participation, provides a unified evaluation standard for the decision-making and methods adopted by enterprises in the process of disaster participation, and greatly improves the efficiency of enterprise disaster participation. Generally, the government can promote enterprises to participate in disaster management through policy guidance, legal guidance, and practice guidance.

Policy guidance refers to that the government formulates relevant policies or promulgates development plans to guide enterprises to participate in disaster management. Through macro guidance, the government helps enterprises to examine the direction of disaster participation, so as to think about how to participate in disaster management. For example, if the government introduces relevant policies to provide interest free or low interest loans to small enterprises for disaster management, then these enterprises can reduce their own capital investment and turn to the improvement of technology and management. In addition, the development plan issued by the government can also help enterprises to know the possible disasters in the future and the new ways and methods to participate in disaster management.

Legal guidance refers to the use of laws and regulations by governments at all levels to specify what enterprises can and cannot do in the process of disaster participation, so as to draw a clear boundary for enterprises to participate in disaster management. For enterprises, this is not dancing in shackles, but to help enterprises do their duty well, avoid power conflicts with the government, and increase the effectiveness of enterprises participation in disaster management.

Practice guidance refers to that the government takes its own practice as an example to guide enterprises to participate in disaster management in the process of disaster management. The experience of government response to Hurricane Katrina in the United States shows that although the government needs to learn from the enterprises in disaster management, the government also has something worth learning from enterprises. Although the government led disaster management model has a series of disadvantages, the government has the advantages that enterprises cannot have in terms of coordination and resource mobilization. More importantly, the relevant government departments and personnel have accumulated rich disaster management experience in the long-term work, which is often lacking in enterprises and enterprise managers. In the process of disaster management, the government should set a good example for enterprises in disaster management, includ- 
ing the importance of disaster management and the introduction and implementation of relevant laws and regulations, so as to build a good platform for enterprises to participate in disaster management, and let enterprises feel that participating in disaster management is an important part of their social responsibility.

\subsection{Provide Support for Enterprises to Participate in Disaster Management}

The government has a wealth of public resources and a strong ability of macro control. When enterprises participate in disaster management, the government should act as a strong backing for enterprises to provide financial, technical, policy, and human resources support for enterprises. The reasonable use of social resources by the government to help enterprises participate in disaster management can greatly reduce the pressure of disaster prevention and mitigation of enterprises, and enable enterprises to focus on the areas they are good at, so as to realize the complementary advantages of enterprises, government and social organizations in disaster management (Figure 3). In addition, the government should absorb the power of enterprises and social organizations to the maximum extent and promote the diversified development of disaster management subjects. At present, the governments of various countries are gradually establishing the resource sharing platform, so as to fully integrate the useful information and resources in the event of disasters, and help enterprises, governments and social organizations realize resource sharing and resource complementarity $[5,6]$.

\section{Key Points for Chinese Government to Promote Enterprises to Participate in Disaster Management}

Since the Wenchuan earthquake, some Chinese enterprises have played their own advantages and made positive contributions in disaster relief [10]. However, the awareness of Chinese enterprises to participate in disaster management is not strong, and the ability to participate in disaster management is not high. The improvement of the awareness and ability of Chinese enterprises to participate in disaster management is inseparable from the guidance and support of the government. From the macro point of view, the government plays a role of encouragement, guidance, and support in enterprises' participation in disaster management. At present, the Chinese government needs to start from the legal, political, and social aspects, and enhance the level of participation in disaster management on the basis of promoting enterprises to improve disaster management capacity.

Firstly, the government should strengthen the construction of the legal system and bring the participation of enterprises in disaster management into the national disaster management system. At present, China's legal system of emergency management is still not perfect, especially the lack of clear provisions on the participation of enterprises in disaster management, and there is no classification for the strength of enterprises of different sizes and types to participate in disaster management $[24,28]$. This is not only easy to lead to lose discipline when enterprises participate in disaster management, but also may lead to some enterprises' bad behavior after the disaster, blindly pursue economic interests and ignore the social responsibility of enterprises. The Chinese government should draw lessons from the advanced experience of international developed countries, and combine with its own reality, formulate and improve the relevant laws and regulations for enterprises to participate in disaster management, incorporate enterprises' participation in disaster management into the national emergency management system through legislation, and clarify the responsibilities and obligations of enterprises at all stages of the whole disaster cycle.

Secondly, it is urgent to strengthen the construction of emergency management system of grass-roots government to build a platform for enterprises to participate in disaster management. In order to improve the level of enterprise participation in disaster management, the government should first establish a relatively perfect emergency management system, and make it an effective platform for enterprises to participate in disaster management, so as to provide system guarantee and good service for enterprises to participate in disaster management. The experience of the United States and Japan shows that the ability 
of enterprises to participate in disaster management has significantly improved. The important reason is that the governments at all levels of the two countries have actively built various platforms for enterprises to participate in disaster management on the basis of improving their own emergency management system, especially by establishing and improving the emergency management institutions of grassroots governments to strengthen the disaster governance capabilities, so as to facilitate the participation of enterprises disaster management provides demonstration and impetus. Although the establishment of the Ministry of Emergency Management in 2018 shows that the Chinese government has promoted the status of emergency management, the system is still imperfect. At present, although China's governments at all levels have established disaster institutions such as emergency management office, the system and mechanism are still not perfect, and it is difficult to create good conditions for enterprises to participate in disaster management [3]. Therefore, it is urgent to improve the system construction by strengthening the construction of the professional team, build a platform for enterprises to participate in disaster management, and give full play to the role of grassroots government in the bridge between enterprises and higher government, and effectively promote the construction of enterprise participation in disaster management system and mechanism.

Thirdly, it is necessary to build a seamless disaster management system between government and enterprises. In summing up the lessons of government inefficiency in Hurricane Katrina relief operations, the United States pointed out that it did not make plans to integrate enterprises into emergency response operations, resulting in a short circuit in the process of coordinating disaster response between the private sector and the federal government. In 2008, the National Response Framework issued by the Department of Homeland Security of the United States fully learned this lesson, and confirmed the role and status of the private sector in disaster management [10]. It clearly pointed out that emergency managers must cooperate seamlessly with enterprises providing hydropower, communication networks, transportation, medical care, security, and other services They should depend on each other. This is of great significance to the construction of China's disaster management system, because compared to the United States, China's disaster management system needs to be strengthened. There are four possible paths for Chinese enterprises to participate in disaster management. The first path is to make clear the channels, departments, or officials to contact and communicate with enterprises in government, and send liaison officers to some important enterprises when disasters occur. The second path is to set up enterprise representatives in government emergency decision-making organs. This not only helps the government to fully consider the suggestions of enterprises in emergency decision-making, but also helps enterprises understand national policies and actively assist the government in disaster management. The third path is that the government emergency departments should strengthen the formulation of emergency plans for enterprises, especially for high-risk industries, so that they can connect with the government emergency plans. The fourth path is that enterprises should participate in the emergency training exercises organized by the government, so as to find and correct the incongruity between each other and ensure the seamless connection in the emergency response.

Fourthly, it is urgent to establish and improve China's disaster insurance system. As a specialized risk management industry in the financial industry, the unique advantages of risk transfer and disaster risk reduction have been highly valued in disaster management, and have become the "shock absorber" to maintain the sustainable and stable development of social economy. At present, there are not only a few kinds of disaster insurance in China, but also a small amount of claims. In the world, catastrophe insurance claims generally account for $30-40 \%$ of disaster losses, while the insurance coverage of natural disasters in China is less than 2\% [8]. There are only a few special disaster insurance programs for enterprises, which is obviously not conducive to the disaster management work of enterprises and the post disaster recovery of enterprises, thus affecting the ability of enterprises to participate in disaster management. The Chinese government should vigorously promote the work of natural disaster insurance, establish and improve the natural disaster 
insurance system as soon as possible, so that relevant enterprises can participate in disaster management by providing disaster insurance products, and more enterprises can improve disaster prevention and mitigation capabilities through disaster insurance.

Fifthly, the government should decentralize its power to fully stimulate the potential and vitality of enterprises to participate in disaster management. The natural advantages of enterprises in capital, technology, and equipment are beyond the reach of the government. The potential of enterprises should be brought into full play and should become an important part of national emergency response capability. One of the reasons why Chinese enterprises cannot participate in disaster management well is that the existing national policies restrict the vitality of enterprises to participate in disaster management. Enterprises can only respond to disasters passively, and their own advantages in disaster management cannot be fully utilized. The government should give enterprises full trust and appropriate decentralization, so that they can have the opportunity to lead the people in their communities to do a good job in disaster prevention. When the disaster occurs, enterprises have the right to obtain more information resources, make accepted decisions, so they can directly participate in community disaster response.

Sixthly, it is urgent to establish an evaluation system for enterprises' participation in disaster management. The scientific evaluation mechanism is an important prerequisite for enterprises to participate in disaster management, and the evaluation of an enterprise is constantly changing with the development of society. Economic benefit has always been the most important index to measure an enterprise, but with the progress of society, people's requirements for enterprises have exceeded the economic benefits. Enterprises social responsibility has become an important index to evaluate enterprises, and actively participating in disaster management has become an important content of enterprises' social responsibility [10]. In order to promote enterprises to participate in the construction of disaster management capacity, it is necessary for the government to bring the capacity construction of disaster management into the scope of enterprises' social responsibility for management. The important way is to establish a complete evaluation mechanism of enterprises' participation in disaster management, including the establishment of scientific evaluation index system and the establishment of a complete evaluation system. The feasible way is to entrust a third-party organization to establish the relevant evaluation index system, conduct a comprehensive evaluation once a year, and publish the evaluation results publicly. Through the establishment of an evaluation system, enterprises' willingness to participate in disasters can be enhanced, and enterprises' participation in disaster management can be normalized and institutionalized gradually.

The above measures provide a set of feasible mechanisms for enterprises to participate in disaster management from the aspects of legal system construction, platform construction, government enterprise docking system construction, disaster insurance system construction, power and responsibility allocation construction, and enterprise disaster reduction capacity construction. Among them, the construction of the legal system is not only the basis of promoting enterprises to participate in disaster management, but also the fundamental guarantee. The relevant laws and policies of disaster management will run through the disaster management, so as to legalize the enterprises' participation in disaster management and make it a compulsory corporate responsibility. In practice, there are laws to abide by and punishment must be given to those who break the law, so as to effectively promote enterprises to actively participate in disaster management. On this basis, platform construction, government enterprise seamless docking system, and perfect disaster insurance system can provide effective institutional guarantee for enterprises to participate in disaster management when disaster occurs, which is an important aspect of improving enterprises' participation in disaster management. The allocation of powers and responsibilities and the construction of enterprise disaster reduction capacity are the important guarantee to enhance the efficiency of enterprise participation in disaster management. These measures provided by the government include not only the requirements for the construction of relevant systems and mechanisms in the government, but also the require- 
ments for the enterprises themselves. Only by adapting to each other can the enterprises play an effective role in disaster management.

\section{Summary}

Through the above analysis, we can see that enterprises play an important role in disaster management, and the government should bear the corresponding responsibility in enterprise disaster management. Due to the shortcomings of enterprises' participation in disaster management, the government should play a corresponding role to ensure enterprises' participation in disaster management. For the enterprises themselves, how to effectively play an important role in disaster management has not only become an urgent issue for the development of Chinese enterprises, but also an urgent need for the Chinese government to improve the national emergency management system and enhance the national emergency management ability.

Enterprises' participation in disaster management still needs to be further improved. In terms of public policy, we should improve the design of enterprises' participation system in the disaster management system, establish a trinity of government, enterprise, and society disaster management system and mechanism, improve the status of enterprises in national disaster management, clarify the responsibilities of enterprises in disaster management, and create conditions for enterprises to participate in disaster management. For the government, on the one hand, optimize the structural relationship among government, enterprise, and society in disaster management [10]. On the other hand, we should make clear the role of enterprises in disaster management through legislation, and give full play to the role of enterprises in community, regional, and even national disaster management $[16,28]$. In order to better implement the above policies and further highlight the important role of enterprises in disaster management, the enterprise department urgently needs to be added to the national disaster management organization, and the position and responsibilities of the enterprise department in the disaster management organization system are clearly defined. National and local governments create a good environment for enterprises to participate in disaster management by formulating specific measures.

For enterprises, on the basis of further strengthening their own disaster management, we should recognize the important role of participating in disaster management from the perspective of social responsibility, strengthen the capacity-building of enterprises participating in disaster management based on strategic advantages, and make participation in disaster management normalized, specialized, and strategic. By strengthening their own disaster management capacity-building, it will be integrated into the development of enterprises to normalize disaster management and lay a solid foundation for participating in disaster management [8]. Through participation in the whole process of disaster management to achieve diversification of participation ways, through cooperation with the government and non-governmental organizations to achieve participation in the way of network. It is necessary to strengthen the construction of enterprises' ability to participate in disaster management based on strategic advantages, combining the participation in disaster activities with the improvement of enterprises' long-term competitive potential, and systematically using their own unique advantages to maximize the social and economic value created by disaster participation activities, so as to truly realize the strategization of enterprises' participation in disaster management [10].

In addition, the government and enterprises should pay attention to the disaster defense ability of residents in disaster risk areas in the process of disaster management. The disaster defense ability of residents mainly includes physical defense ability, social defense ability, and humanistic defense ability [3]. The physical defense capacity is mainly the ability of residents to reduce disaster through engineering measures. Social defense ability is mainly the ability of residents to reduce disaster through non-engineering measures. Humanistic defense ability mainly refers to the awareness, culture, and ability of disaster prevention and reduction formed by residents of communities. Residents in different regions have different disaster defense capabilities due to the differences of disaster risk 
level and disaster experience. Therefore, the government and enterprises should formulate scientific disaster management measures according to local and personal conditions in the process of participating in disaster management.

Author Contributions: All authors contributed equally to this work. All authors wrote, reviewed, and commented on the manuscript. All authors have read and agreed to the published version of the manuscript.

Funding: This research was funded by the National Basic Research Program of China, grant number 2018YFC1509003, 2019YFC1510202 and 2018YFC0806900, the National Natural Science Foundation of China, grant number 41701103, 41775078, 41801064 and 71790611, MOST Special Fund for the Fourth National Assessment Report on Climate Change, and the Beijing Social Science Foundation Project, grant number 19JDGLA008.

Institutional Review Board Statement: Not applicable.

Informed Consent Statement: Not applicable.

Data Availability Statement: No new data were created or analyzed in this study. Data sharing is not applicable to this article.

Acknowledgments: The authors would like to acknowledge the helpful comments of anonymous referees of the journal, who have helped to improve this paper.

Conflicts of Interest: The author declares that no conflict of interest exists.

\section{References}

1. Alexander, D.E. Globalization of disaster: Trends, problems and dilemmas. J. Int. Aff. 2006, 59, 1-22.

2. Kong, F.; Wang, Y.; Lv, L.; Meng, Y.; Shi, P. Progress and prospect of the global and complex impact of catastrophe on economy in the context of interconnection. J. Cent. China Norm. Univ. Nat. Sci. Ed. 2018, 52, 871-882. (In Chinese)

3. Kong, F. Better understanding positive and negative impacts of disasters on regional economies, with special reference to China. J. Contingencies Crisis Manag. 2020, 28, 479-481. [CrossRef]

4. Kong, F.; Lv, L.; Wang, P.; Yan, X.; Wang, Y. Basic definition and characteristics of disaster defense capability. J. Catastrophol. 2018, 33, 1-4. (In Chinese)

5. Kong, F. Re-discussion on the basic definition and characteristics of disaster defense. J. Catastrophol. 2020, 35, 6-10. (In Chinese)

6. Kong, F. Third discussion on the basic definition and characteristics of disaster defense. J. Catastrophol. 2021, 36, 1-9. (In Chinese)

7. Cutter, S.L. Resilience to what? Resilience for whom? Geogr. J. 2016, 182, 110-113. [CrossRef]

8. Li, M. Study on Raising Social Fund to Redistribute Disaster Risk with Lottery and Insurance. Ph.D. Thesis, Beijing Normal Universty, Beijing, China, 2016. (In Chinese).

9. Kong, F. Understanding government's role in integrated disaster risk governance. J. Public Aff. 2020, 20, e2452. [CrossRef]

10. Shi, P. IHDP/Future Earth-Integrated Risk Governance Project Series: Disaster Risk Science; Springer: Berlin/Heidelberg, Germany, 2019.

11. World Economic Forum. The Future Role of Civil Society; World Economic Forum: Cologny, Switzerland, 2013; p. 5.

12. United Nations International Strategy for Disaster Reduction (UNISDR). Global Assessment Report on Disaster Risk Reduction 2015; United Nations: New York, NY, USA, 2015.

13. United Nations International Strategy for Disaster Reduction (UNISDR). Sendai Framework for Disaster Risk Reduction 2015-2030; United Nations: New York, NY, USA, 2015.

14. United Nations International Strategy for Disaster Reduction (UNISDR). Global Assessment Report on Disaster Risk Reduction 2019; United Nations: New York, NY, USA, 2019.

15. Lv, X. Managing Uncertainty in Crisis: Exploring the Impact of Institutionalization on Organizational Sense-Making; Springer: Berlin/Heidelberg, Germany, 2017.

16. Shi, P.; Xu, W.; Wang, J. Natural Disaster System in China; Springer: Berlin/Heidelberg, Germany, 2016.

17. Liu, Y.; Yin, K.; Chen, L.; Wang, W.; Liu, Y. A community-based disaster risk reduction system in Wanzhou, China. Int. J. Disaster Risk Reduct. 2016, 19, 379-389. [CrossRef]

18. United Nations International Strategy for Disaster Reduction (UNISDR). Global Assessment Report on Disaster Risk Reduction 2009; United Nations: New York, NY, USA, 2009.

19. State Council of China. Review of the Authoritative Release of the Joint Prevention and Control Mechanism of the State Council. 2020. Available online: http:/ / sousuo.gov.cn/column/49276/0.htm (accessed on 12 December 2020).

20. Lewis, T.; Nickerson, D. Self-insurance against natural disasters. J. Environ. Econ. Manag. 1989, 16, 209-223. [CrossRef]

21. Xue, L. Evolution of emergency management system in China. Adm. Reform 2010, 8, 22-24. (In Chinese)

22. Cummins, J.D. Should the government provide insurance for catastrophes? Fed. Reserve Bank Saint Louis Rev. 2006, 88, 337-379. [CrossRef] 
23. Zhong, K. One case, three systems: The basic framework of China's emergency management system. Nanjing Soc. Sci. 2009, 11, 83-89. (In Chinese)

24. Zhong, K. Evolution and development of China's emergency management institutions: An observation based on coordination perspective. Public Manag. Policy Rev. 2018, 7, 21-36. (In Chinese)

25. United Nations International Strategy for Disaster Reduction (UNISDR). Global Assessment Report on Disaster Risk Reduction 2011; United Nations: New York, NY, USA, 2011.

26. United Nations International Strategy for Disaster Reduction (UNISDR). Hyogo Framework for Action 2005-2015: Building the Resilience of Nations and Communities to Disasters; United Nations: New York, NY, USA, 2005.

27. United Nations International Strategy for Disaster Reduction (UNISDR). Living with Risk: A Global Review of Disaster Reduction Initiatives; United Nations: New York, NY, USA, 2004.

28. United Nations International Strategy for Disaster Reduction (UNISDR). Global Assessment Report on Disaster Risk Reduction 2013; United Nations: New York, NY, USA, 2013. 